\title{
Spatial ecology of Hydropsyche incognita (Trichoptera: Hydropsychidae) in the Carpathians
}

\author{
Mãlina PÎRVU ${ }^{1,2}$, Claudia ZAHARIA ${ }^{3}$, Alina SATMARI ${ }^{4}$ and LuCIAN PÂRVULESCU ${ }^{1}$ \\ ${ }^{1}$ Department of Biology-Chemistry, Faculty of Chemistry, Biology, Geography, West University of Timişoara, Timișoara, Romania; \\ e-mails: malina.pirvu@e-uvt.ro; lucian.parvulescu@e-uvt.ro \\ ${ }^{2}$ Department of Systems Ecology and Sustainability, Faculty of Biology, University of Bucharest, Bucharest, Romania \\ ${ }^{3}$ Department of Mathematics, Faculty of Mathematics and Computer Science, West University of Timişoara, Timişoara, Romania; \\ e-mail: czaharia@math.uvt.ro \\ ${ }^{4}$ Department of Geography, Faculty of Chemistry, Biology, Geography, West University of Timișoara, Timişoara, Romania; \\ e-mail: alina.satmari@cbg.uvt.ro
}

Key words. Trichoptera, Hydropsychidae, Hydropsyche incognita, ecological preferences, spatial analysis, species distribution modelling

\begin{abstract}
Caddisflies are often used in studies on freshwater ecosystem ecology because of their aquatic-dependent larvae. The present study addresses the ecological affinities of larvae of Hydropsyche incognita in terms of the pattern of distribution of this species in the Romanian Carpathians using a boosted regression trees (BRT) model. A population cluster located in the western Romanian Carpathians was identified by the spatial analysis. The statistical model revealed that this species prefers a neutral to low-alkaline $\mathrm{pH}$, high levels of dissolved oxygen, low conductivity, fast flowing water, moderate sized rivers at an altitude below $600 \mathrm{~m}$ a.s.l. and low concentrations of organic pollutants. An eastward decrease in the frequency of $H$. incognita populations was recorded along rivers in the Carpathians. The predictions derived from the BRT model on sites outside the population cluster suggest that many locations in the central and eastern Romanian Carpathians are suitable for H. incognita. However, this species was found at only a few of these locations. In contrast, some populations in this area were found in habitats predicted as unsuitable. There are several possible explanations of this, one of which is random dispersion of the species by flying adults.
\end{abstract}

\section{INTRODUCTION}

Environmental heterogeneity is considered to be one of the most important factors influencing the community structure of many taxa; therefore research focusing on spatial distribution determined by environmental factors is an open scientific challenge (Macneale et al., 2005; Landeiro et al., 2012). An understanding of the combined natural and anthropogenic influences on species distributions may enhance our knowledge of biogeographical patterns and also indicate appropriate conservation measures. Caddisflies (Insecta: Trichoptera) are often used in studies on freshwater ecosystem ecology because they have aquatic larvae (Lin \& Liu, 2006; Ruiz-García et al., 2012; Ligeiro et al., 2013). As they are present in a wide range of rivers and streams, and are sensitive to water quality (Bonada et al., 2004; Cid et al., 2010; Kail et al., 2012; Rizo-Patrón et al., 2013), the EU Water Framework Directive 2000/60/ EC (Council of Europe, 2000) considers caddisflies to be valuable biological indicators. Caddisflies are also dynamic components of the energy flow in aquatic ecosystems (Resh \& Rosenberg, 1984; Holzenthal, 2009).

According to Schmid (1980), species of the genus $\mathrm{Hy}$ dropsyche Pictet, 1834 are present in most freshwater aquatic systems worldwide. To date, more than 60 species belonging to this genus have been identified in Europe (Malicky, 2013), with H. incognita Pitsch 1993 a com- mon species in Central and Western Europe (Múrria et al., 2010). It is suggested that the eastern limit to the distribution of this species is the Balkan and Carpathian ranges (Kumanski, 2007; Graf et al., 2008; Ciubuc, 2010). However, the range of this species is still insufficiently known, but was probably shaped by Pleistocene glacial events as is the case for other similar taxa (Pauls et al., 2006; Engelhardt et al., 2011). Even though it is claimed that species of Hydropsyche are reliable bioindicators of water quality (Cain \& Luoma, 1998; Bonada et al., 2004; Barata et al., 2005; Bonada et al., 2005; Petrin et al., 2007; MacedoSousa et al., 2008; Ratia et al., 2012), little is known about the ecology of many of the species in this genus. H. incognita prefers moderate to faster flowing water (Elexová \& Némethová, 2003; Wolf et al., 2009) and is less tolerant of poor quality water than most of the other species of the genus Hydropsyche (Pitsch, 1993; Kail et al., 2012).

Modelling species distributions based on environmental data is an important goal of ecological research (De Frutos et al., 2007). This paper provides additional information on the ecological preferences of $H$. incognita and an account of its current distribution in Romania. The results of this study may provide valuable data for the international effort to develop strategies for achieving the long-term conservation of aquatic ecosystems. 


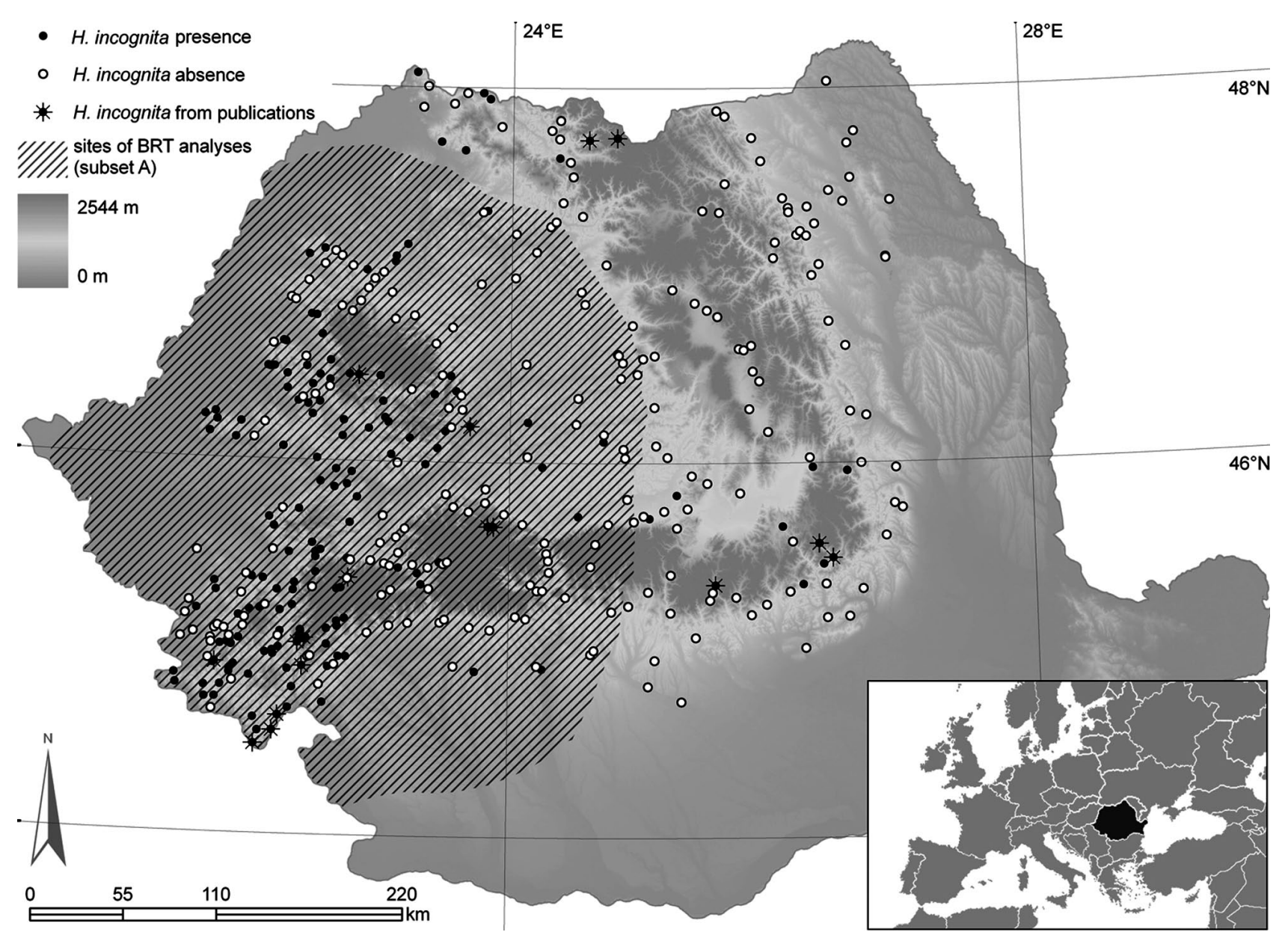

Fig. 1. Map showing the distribution of H. incognita in Romania and the spatial clustering of populations.

\section{MATERIAL AND METHODS}

\section{Distribution and ecological variables}

A three-year summer field investigation (2009-2011) was conducted in an area comprising the Carpathian Arc and plateaus in Romania (Fig. 1). In total 369 randomly selected sections of rivers were sampled using a hand net $(250-\mu \mathrm{m}$ mesh). Each of the sites investigated included on average a $100 \mathrm{~m}$ stretch of river, comprising five roughly equal subsamples reflecting the existing microhabitats. All the caddisfly larvae collected were processed in the laboratory. To avoid misidentification, as the larval stages of $H$. incognita and $H$. pellucidula are very similar, the latest taxonomic keys to larvae by Waringer \& Graf (2011) and Múrria et al. (2010) were used. We only identified full grown larvae as only they have the morphological traits needed for reliable identification. The specimens studied are lodged in the collection of the West University of Timisoara.

Altitude, water velocity, average river width and depth were recorded at each site sampled, together with several physicochemical parameters: conductivity, $\mathrm{pH}$, dissolved oxygen, $\mathrm{N}$ nitrate, $\mathrm{N}$-nitrite, $\mathrm{N}$-ammonia and soluble reactive phosphorus (SRP). These physico-chemical parameters were analyzed using triple subsamples for each sector sampled, using a HACH-Lange (Düsseldorf, Germany) multi-parameter and field spectrophotometer following standard procedures. Water velocity was measured using a Flowatch flow-meter (JDC Electronic SA, Switzerland). Between 10 and 20 measurements were recorded in each sector sampled, depending on the heterogeneity of water flow.

\section{Data analyses}

Given the uneven distribution of $H$. incognita in Romania, with populations concentrated mostly in the western part of the country, we aimed to evaluate the ecological parameters associated with this pattern and detect any possible eastward dispersion of the species. For this reason we performed a spatial analysis in order to determine the clustering of populations in Romania. With the purpose of increasing the reliability of distributional data for this species in the region, we completed the dataset for the spatial analysis based on adult $H$. incognita occurrence recorded in recent literature (Ciubuc, 2010).

The spatial analyses were performed using the ArcMap10 Geographical Information System (GIS) with Spatial Analyst and Spatial Statistics toolboxes (ESRI, Redlands, CA, USA). The spatial autocorrelation of the sites sampled was tested using Moran's I index. This index describes and quantifies the similarity among spatial locations as a function of distance (De Frutos et al., 2007; Merbitz et al., 2012), allowing a more synoptic view of patterns over a large area (Pandit \& Laband, 2007). In order to identify the range with highest autocorrelations, the Z-score was used with the Euclidean distance method for different fixed distance bands from 10 to $300 \mathrm{~km}$. According to Aguilar \& Farnworth (2013) and Pandit \& Laband (2007) the statistically most significant positive Z-score represents the optimum clustering distance. The peak value for the Z-score was recorded at a distance of $210 \mathrm{~km}$. This value was used for running a Point Density Analysis, thereby splitting the data into two classes using the quantile method and Nearest Neighbour resampling. 
TABLE 1. Basic statistics of the ecological factors measured at the sites where $H$. incognita occurred, and their overall ranges.

\begin{tabular}{|c|c|c|c|c|}
\hline \multirow[b]{2}{*}{ Parameter (unit) } & \multicolumn{3}{|c|}{ H. incognita presence } & \multirow{2}{*}{$\begin{array}{c}\text { Overall } \\
\text { range } \\
\text { (min-max) }\end{array}$} \\
\hline & $\begin{array}{c}\text { Range } \\
\text { (min-max) }\end{array}$ & Mean & $\mathrm{SD}$ & \\
\hline Water & $0.003-1.4$ & 0.49 & 0.28 & $0.002-2.6$ \\
\hline (m a.s.1.) & $60-1010$ & 413.6 & 188.3 & $60-1625$ \\
\hline Average river width (m) & $0.4-11.5$ & 1.9 & 1.2 & $0.25-25$ \\
\hline Average river depth (m) & 0.04 & 0.3 & 0.2 & $0.04-2.15$ \\
\hline pH & $6.7-9$ & 7.9 & 0.4 & $6.58-10.85$ \\
\hline Dissolved oxygen $\left(\mathrm{mg} / \mathrm{l}_{2}\right)$ & $6.63-10.41$ & 8.93 & 0.71 & $1.05-12.85$ \\
\hline Conductivity $(\mu \mathrm{S} / \mathrm{cm})$ & $26.7-1323$ & 277 & 223.3 & $26.7-2089$ \\
\hline $\mathrm{N}$-nitrate $\left(\mathrm{mg} / \mathrm{l} \mathrm{N}-\mathrm{NO}_{3}\right)$ & $0-1.5$ & 0.31 & 0.29 & $0-1.7$ \\
\hline N-nitrite $\left(\mathrm{mg} / 1 \mathrm{~N}-\mathrm{NO}_{2}\right)$ & $0-0.07$ & 0.007 & 0.009 & $0-0.14$ \\
\hline $\mathrm{N}$-ammonia $\left(\mathrm{mg} / \mathrm{l} \mathrm{N}-\mathrm{NH}_{4}^{+}\right)$ & $0-0.27$ & 0.046 & 0.046 & $0-0.57$ \\
\hline $\mathrm{SRP}\left(\mathrm{mg} / 1 \mathrm{P}-\mathrm{PO}_{4}^{3-}\right)$ & $0.001-2.43$ & 0.244 & 0.39 & $0-2.78$ \\
\hline
\end{tabular}

The 369 sites sampled were grouped into two subsets on the basis of the results of the spatial analyses, thus identifying the area where the distribution could be appropriately analyzed from the perspective of ecological conditions, avoiding false absences caused by the impossibility of colonization rather than unsuitable environments. Subset A, consisting of 261 locations, corresponds to the region with the greatest density of presence points and is situated in the western part of the Romanian Carpathians (Fig. 1). Subset B included the remaining 108 locations. In order to understand which ecological factors may influence the distribution of H. incognita, a Boosted Regression Trees (BRT) classifier was used to differentiate between the locations with species presence and absence, with altitude, water velocity, river width and depth and physico-chemical parameters used as predictors. Using BRT has the advantage that nonlinear relationships between predictor and response variables can be handled easily and that complex interactions between the predictors can be included in the model. A comprehensive description of this method is given by Elith et al. (2008)

The classifier was trained and evaluated using the data of subset A. The BRT model assumed an interaction depth of 3 , a bag fraction of 0.5 and a small learning rate of 0.002 . The optimal number of trees was selected by 10 -fold cross-validation. After evaluation, tests were undertaken to determine whether the model could be further simplified and improved by excluding the least contributing predictors, following which the relative importance of each explanatory variable and the most significant pairwise interactions were determined. Finally, the classifier was used for prediction on subset $\mathrm{B}$ and the findings were compared with existing information on species presence. The criteria used in order to determine the threshold used to convert predicted presence probabilities into predictions of presence/absence were the minimization of the sensitivity-specificity difference and the maximization of the sensitivity-specificity sum (see Liu et al., 2005; JiménezValverde \& Lobo, 2007), both indicating the same optimal value of 0.6. The model was developed in R software (R Development Core Team, Vienna, Austria) (version 2.14.0), using the "dismo" package, version 0.7-23 (Hijmans et al., 2012).

Finally, we wanted to verify whether other hydropsychids acting as competitors could influence the distribution of $H$. incognita. To that end we compared the relative frequencies of occurrence of these species at the sites where $H$. incognita was present with those where it was absent. We used a proportion comparison test, performed in R software.

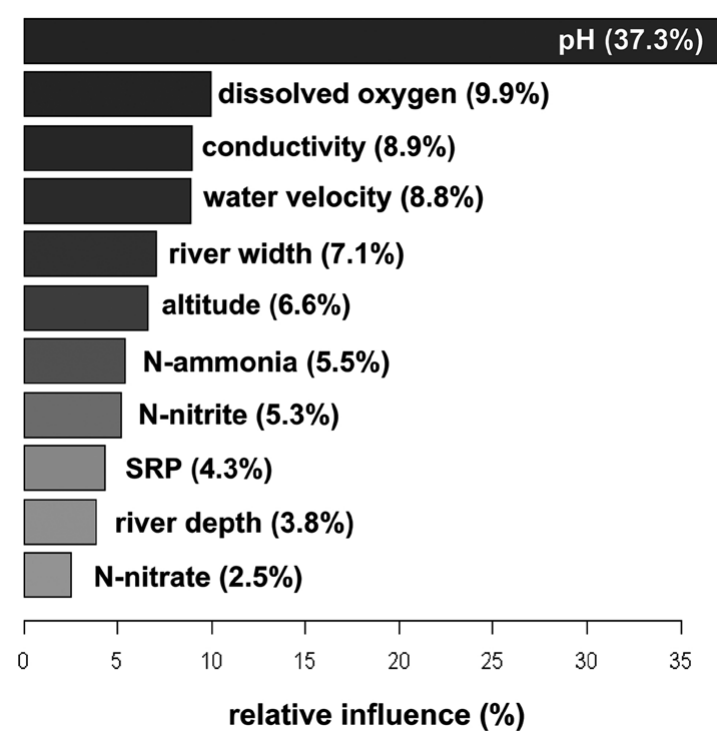

Fig. 2. Relative influence of the ecological factors included in the Boosted Regression Trees (BRT) model used to predict the probability of $H$. incognita being present.

\section{RESULTS}

Along with $H$. incognita, five other hydropsychid species were recorded at the locations studied: $H$. instabilis, $H$. angustipennis, $H$. pellucidula, $H$. fulvipes and $H$. modesta. Most populations of $H$. incognita were found in western river basins and decreased in frequency in an easterly direction. The spatial analyses revealed a cluster of populations (subset A) located in the west of Romania (Fig. 1), including 261 sites of which 131 (50.1\%) were populated by $H$. incognita. Subset B consisted of the remaining 108 locations studied, including $13(12 \%)$ where the species was present.

The basic statistics of the ecological parameters investigated are given in Table 1. The BRT model developed for subset A demonstrated a good ability to discriminate between presence and absence (mean AUC: 0.855, standard error: 0.026 , evaluated within cross-validation). All the predictors initially chosen were retained in the final model, as subsequent attempts to improve it by excluding those that were least contributing did not lead to a better overall performance. Partial dependence plots showed the marginal influence of each explanatory variable on the probability of presence, after accounting for the average effects of all other variables in the model. The most important factor influencing species presence was $\mathrm{pH}$, its relative influence exceeding that of the combined next most significant four predictors (Fig. 2). The presence probability related to $\mathrm{pH}$ is monotonic decreasing over the range sampled, showing a rapid decline at $\mathrm{pHs}>8.5$ (Fig. 3a). In addition, species occurrence seemed to be favoured by high levels of dissolved oxygen (greater than $9 \mathrm{mg} / \mathrm{l}$ ) and low conductivity (less than $600 \mu \mathrm{S} / \mathrm{cm}$ ) (Fig. 3b and c). The presence probability increased with water velocity over the range $0-0.5$ $\mathrm{m} / \mathrm{s}$, after which it generally remained constant (Fig. 3d). Presence probability was also influenced negatively by increase in river width, altitude, $\mathrm{N}$-nitrites and $\mathrm{N}$-nitrates 

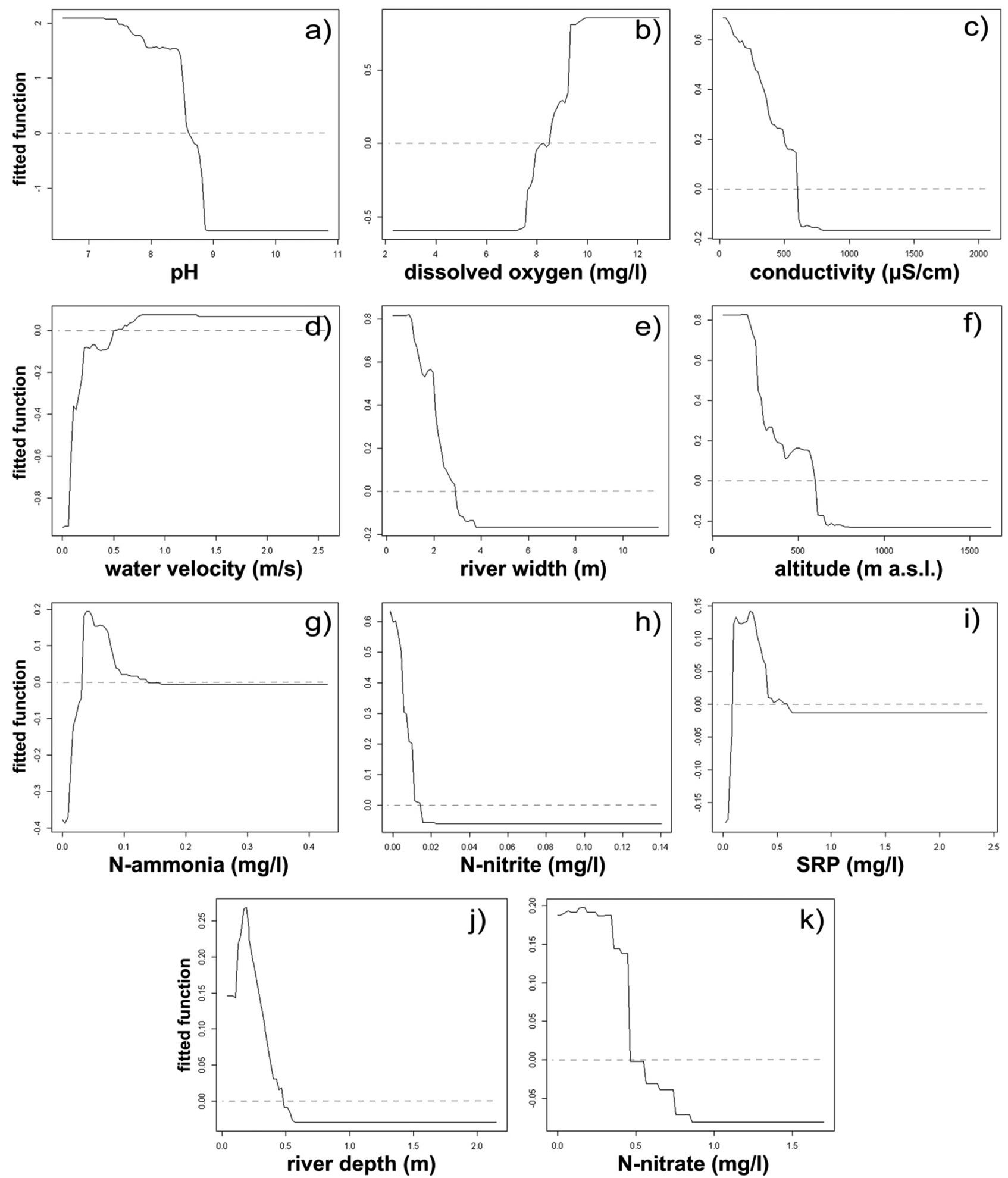

Fig. 3. Partial dependence plots showing the influence of ecological factors on the prediction of the probability of $H$. incognita being present. All other factors in the model are considered constant. Dotted lines were added at zero to improve plot readability.

(Fig. 3e, f, h and k), whereas there was a more pronounced unimodal response to N-ammonia, SRP and river depth, with peak values occurring at around $0.1-0.3 \mathrm{~m}$ for the first parameter and $0.2-0.4 \mathrm{mg} / \mathrm{l}$ for the latter two (Fig. $3 \mathrm{~g}$, i and $\mathrm{j}$ ). The most important pairwise interactions identified in the model were those between $\mathrm{pH}$ and conductivity, and between $\mathrm{pH}$ and dissolved oxygen (Fig. 4).
For subset $\mathrm{B}, H$. incognita was predicted to be present in 28 of the 108 locations studied, mainly situated in the central-eastern Romanian Carpathians. It should be noted that only six of the 13 actual presence points in this dataset were predicted as positive (Fig. 5). The sites with positive prediction were found to be well-inhabited by H. incognita, 

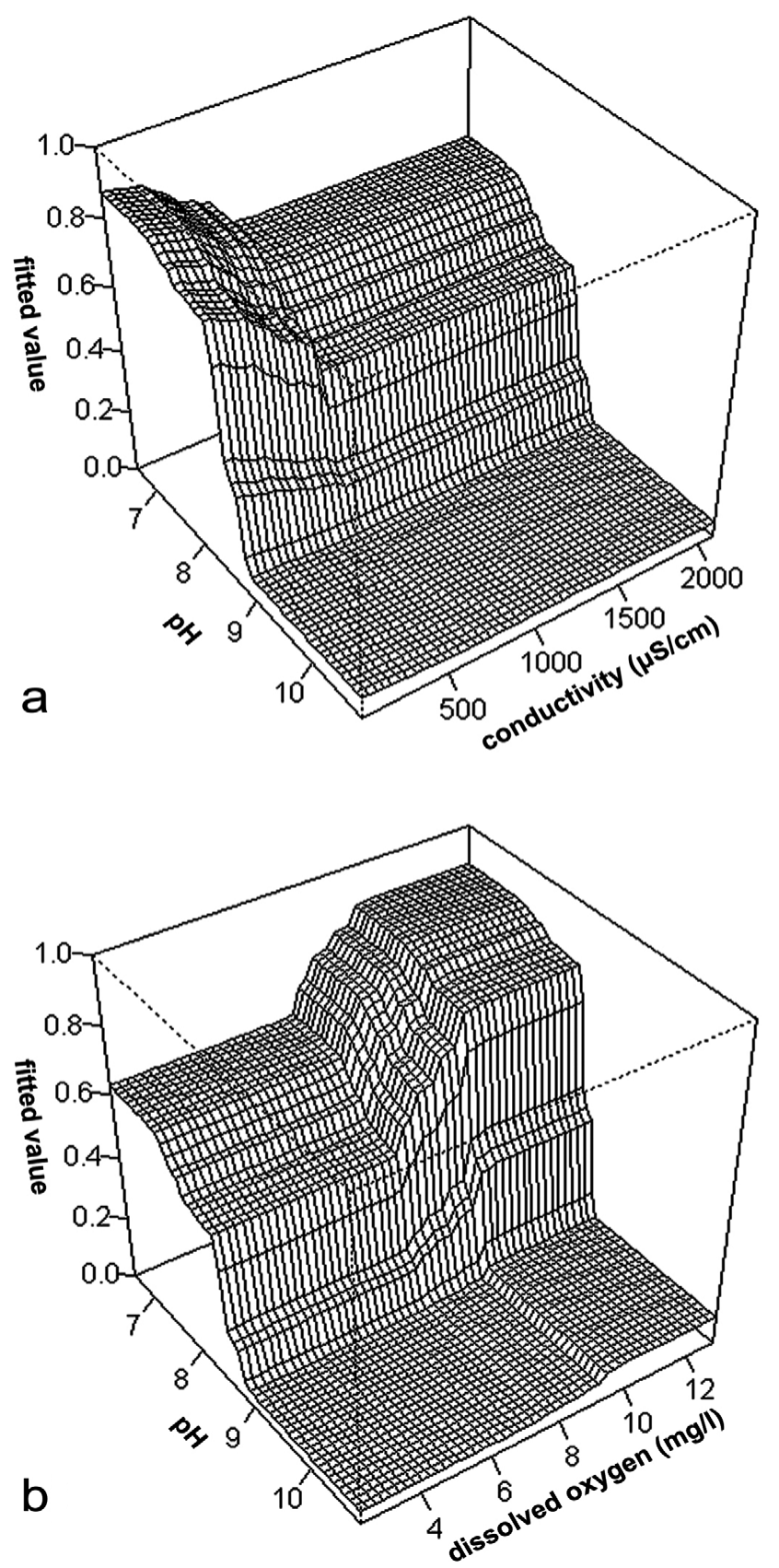

Fig. 4. Joined partial dependence plots displaying the effect of each respective pair of factors on the probability of $H$. incognita being present when all other factors in the model are kept constant.

whereas the population size was much smaller in the sites where the species was predicted to be absent (Table 2).

\section{DISCUSSION}

The BRT model showed that of the parameters studied $\mathrm{pH}$ is the most important factor explaining the distribution of H. incognita in the Romanian Carpathians. It is known that $\mathrm{pH}$ influences the distribution of other species of $\mathrm{Hyd}$ ropsyche, with larval abundance more strongly dependent on $\mathrm{pH}$ than on other physico-chemical factors (Petrin et al., 2007). We note that the lowest $\mathrm{pH}$ value recorded at the sites sampled was close to neutral (see Table 1), so that the
TABLE 2. The number of individuals of $H$. incognita recorded at sites sampled outside the main population cluster and the corresponding prediction of the BRT model.

\begin{tabular}{lcc}
\hline Site & No. of individuals & BRT prediction \\
\hline Valea Holita & 10 & Positive \\
Valea Mare & 8 & Positive \\
Vicleanul Mare & 1 & Negative \\
Babei & 8 & Positive \\
Sarasau & 2 & Negative \\
Baleasa & 3 & Negative \\
Iazul & 8 & Negative \\
Venetia & 12 & Positive \\
Floroaia & 2 & Negative \\
Pacura & 1 & Negative \\
Ojda & 9 & Positive \\
Valea Paltinisului & 1 & Negative \\
Lepsa & 10 & Positive \\
\hline
\end{tabular}

BRT model did not consider the influence of moderately low pHs on the distribution of this species. However, the literature suggests that species belonging to the genus $\mathrm{Hy}$ dropsyche prefer $\mathrm{pH}$ values close to neutral, so it is likely that $H$. incognita does not occur in acidic water (Graf et al., 2008).

The optimal ecological conditions for this species are a neutral to low-alkaline $\mathrm{pH}$, high levels of oxygenation and low conductivity. It is suggested that for insect larvae an increase in conductivity adversely affects population growth (Clark et al., 2004; Hassell et al., 2006; Carver et al., 2009).

In addition to the above ecological factors, water velocity also appears to have an important role in determining the distribution of the species, with $H$. incognita preferring moderate to high water velocities. This could be due to the fact that net-spinning caddisflies such as Hydropsyche larvae require fast flowing water, for the efficient functioning of the net they use for obtaining food (Philipson, 1969; Sagnes et al., 2008; Statzner \& Dolédec, 2011). The preference of $H$. incognita for water at lower altitudes (below $600 \mathrm{~m}$ a.s.1.) is also suggested for the north-western Carpathians for the main species of Hydropsyche, including H. incognita (Bálint \& Ujvárosi, 2009). Organic pollutants (dissolved inorganic nitrogen and soluble reactive phosphorus) appear to have little effect on their distributions. Clean water may not be essential, but could be necessitated by other cumulative ecological requirements. It is known that the concentration of organic pollutants in water increases with decrease in altitude.

The results of the predictions based on ecological factors indicated a considerable number of suitable locations for $H$. incognita in the Central and Eastern Carpathians. In addition, the distributions of many of the populations in this area do not conform to the ecological requirements associated with the western population cluster. It is likely that these scattered locations are examples of source-sink dynamics, with flying adults randomly colonizing new water bodies. The expectation is that this kind of colonization does not always result in optimal conditions for the 


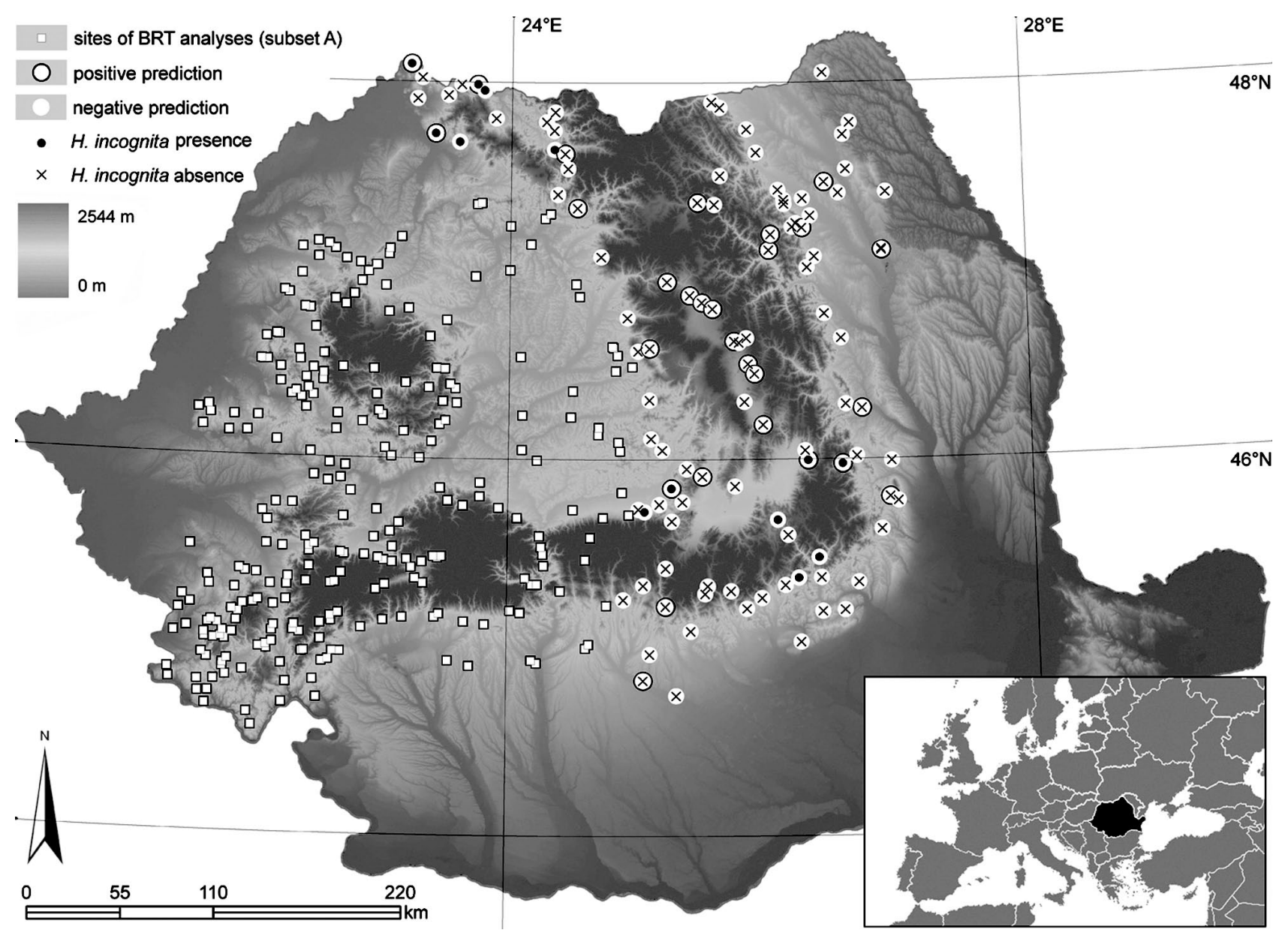

Fig. 5. Predicted distribution of $H$. incognita in Romania outside the spatial cluster.

development of larvae. The survival of newly founded larval populations facing unsuitable conditions is affected and consequently the long-term spreading success is reduced. Yaegashi et al. (2014) revealed by using a fine scale molecular approach that gene flow is more pronounced along water courses than across river basins. Moreover, it is likely that colonization is sensitive to a number of other environmental factors, such as local air temperature, wind direction or drought (Jackson \& Resh, 1991; Waringer, 1991; Landeiro et al., 2012; Storey \& Quinn, 2013), which could result in slow and random dispersion. The analysis of the distribution of related hydropsychids in the locations studied revealed that the proportional incidence of these species was slightly greater at sites where $H$. incognita was present than at those where it was absent (see Table 3 ). This suggests that it is unlikely that the distribution of $H$. incognita was shaped by interactions with competing species of hydropsychid. Nevertheless, the literature sug- gests this might have occurred in other species of this order (Engelhardt et al., 2008, 2011).

The only significant natural barriers in the geographic area studied are the Carpathians, and this species occurs on both sides of this mountain range. Thus, we can easily discard the hypothesis that topography limits their distribution. Also, as the anthropogenic development is relatively uniform throughout Romania (Giurcãneanu, 1970; Schmitt \& Rákosy, 2007), extinction due to anthropological factors is unlikely to have determined their current absence from eastern Romania.

Another possible explanation of the false positive predictions could be the limitations of the model, given that the full range in natural conditions may not have been encountered at the sites sampled. Also, we cannot dismiss the existence of additional predictors of this species distribution that were not included in our study.

TABLE 3. Results (p-values) of tests comparing the proportional incidence of the other five hydropsychid species recorded at the sites where $H$. incognita was present/absent, respectively.

\begin{tabular}{|c|c|c|c|c|c|}
\hline & H. instabilis & H. angustipennis & H. pellucidula & H. fulvipes & H. modesta \\
\hline H. incognita present (144 sites) & 15 & 38 & 38 & 4 & 0 \\
\hline H. incognita absent (225 sites) & 17 & 37 & 35 & 0 & 2 \\
\hline p-value & 0.4454 & 0.02904 & 0.01577 & $\mathrm{~N} / \mathrm{A}^{*}$ & $\mathrm{~N} / \mathrm{A}^{*}$ \\
\hline
\end{tabular}

* Insufficient data for valid comparison. 
The western distribution in Romania is also similar to the findings of other studies conducted in the Balkan Mountains in Bulgaria (Kumanski, 2007). However, the biogeography of $H$. incognita is still poorly known. Several studies support the hypothesis that the existence of various refuges in the Southern Alps and Western Carpathians enabled many freshwater species to survive critical periods during Pleistocene glaciations (Bálint et al., 2008; Schmitt, 2009; Theissinger et al., 2011, 2013; Pârvulescu et al., 2013). The clustered pattern in the west of the Carpathians may suggest a postglacial radiation from a glacial refuge. Future molecular studies are needed to complete the biogeographical picture for $H$. incognita.

ACKNOWLEDGEMENTS. This work was supported by the CNCS-UEFISCDI grant "The stone crayfish (Austropotamobius torrentium), distribution in Romanian habitats, ecology and genetics of populations", project number PCE-1458/2008, funded by the Romanian National Authority for Scientific Research. We want to express our gratitude to three anonymous reviewers whose comments and suggestions greatly improved the manuscript.

\section{REFERENCES}

Aguilar G.D. \& Farnworth M.J. 2013: Distribution characteristics of unmanaged cat colonies over a 20 year period in Auckland. - N. Z. Appl. Geogr. 37: 160-167.

BÁlint M. \& UjVÁrosi L. 2009: Distribution patterns of Hydropsyche incognita (Pitsch, 1993) and H. pellucidula (Curtis, 1834) in Transylvania (Romania), with special reference to their ecological requirements (Trichoptera: Hydropsychidae). - Bull. Soc. Nat. Luxemb. 110: 167-172.

Bálint M., Barnard P.C., Schmitt T., Ujvárosi L. \& Popescu O. 2008: Differentiation and speciation in mountain streams: a case study in the caddisfly Rhyacophila aquitanica (Trichoptera). - J. Zool. Syst. Evol. Res. 46: 340-345.

Barata C., Lekumberri I., Vila-Escalé M., Prat N. \& Porte C. 2005: Trace metal concentration, antioxidant enzyme activities and susceptibility to oxidative stress in the tricoptera larvae Hydropsyche exocellata from the Llobregat river basin (NE Spain). - Aquat. Toxicol. 74: 3-19.

Bonada N., Zamora-Muñoz C., Rieradevall M. \& Prat N. 2004: Ecological profiles of caddisfly larvae in Mediterranean streams: implications for bioassessment methods. - Environ. Pollut. 132: 509-521.

Bonada N., Vives S., Rieradevall M. \& Prat N. 2005: Relationship between pollution and fluctuating asymmetry in the pollution-tolerant caddisfly Hydropsyche exocellata (Trichoptera, Insecta). - Arch. Hydrobiol. 162: 167-185.

CAIN D.J. \& LuOma S.N. 1998: Metal exposures to native populations of the caddisfly Hydropsyche (Trichoptera: Hydropsychidae) determined from cytosolic and whole body metal concentrations. - Hydrobiologia 386: 103-117.

Carver S., Storey A., Spafford H., Lynas J., Chandler L. \& WeINSTEIN P. 2009: Salinity as a driver of aquatic invertebrate colonisation behaviour and distribution in the wheatbelt of Western Australia. - Hydrobiologia 617: 75-90.

Cid N., Ibáñez C., Palanques A. \& Prat N. 2010: Patterns of metal bioaccumulation in two filter-feeding macroinvertebrates: Exposure distribution, inter-species differences and variability across developmental stages. - Sci. Total Environ. 408: 2795-2806.
Ciubuc C. 2010: [Caddisflies in Romania, Class Insecta, Order Trichoptera, Suborders Spicipalpia And Annulipalpia - Bioindicators of Freshwater]. MiniEd, Iaşi, 299 pp. [in Romanian].

Clark T.M., Flis B.J. \& Remold S.K. 2004: Differences in the effects of salinity on larval growth and developmental programs of a freshwater and a euryhaline mosquito species (Insecta: Diptera, Culicidae). - J. Exp. Biol. 207: 2289-2295.

COUnCIL OF Europe 2000: Directive 2000/60/EC of the European Parliament and of the Council of 23 October 2000 Establishing a Framework for Community Action in the field of Water Policy. European Commission, Brussels, 67 pp.

De Frutos A., Oleab P.P. \& Verab R. 2007: Analyzing and modelling spatial distribution of summering lesser kestrel: The role of spatial autocorrelation. - Ecol. Model. 200: 33-44.

Elexová E. \& Némethová D. 2003: The effect of abiotic environmental variables on the Danube macrozoobenthic communities. - Limnologica 33: 340-354.

Elith J., Leathwick J.R. \& Hastie T. 2008: A working guide to boosted regression trees. J. Anim. Ecol. 77: 802-813.

Engelhardt C.H.M., Pauls S.U. \& HaAse P. 2008: Population genetic structure of the caddisfly Rhyacophila pubescens, Pictet 1834, north of the Alps. - Fund. Appl. Limnol. 173: 165-176.

Engelhardt C.H.M., HaAse P. \& Pauls S.U. 2011: From the Western Alps across Central Europe: Postglacial recolonisation of the tufa stream specialist Rhyacophila pubescens (Insecta, Trichoptera). - Front. Zool. 8: 10.

GiURCÃNEANU C. 1970: [Anthropogenic changes in the natural landscape of the Romanian Carpathians.] In Badea L., Dragomirescu Ș. \& Santa C. (eds): [Physical Geography Symposium of the Carpathians.] Institute of Geography, Bucharest [in Romanian].

Graf W., Murphy J., Dahl J., Zamora-Muñoz C. \& López-RodRÍGUEZ M.J. 2008: Distribution and Ecological Preferences of European Freshwater Organisms - Trichoptera. Pensoft, Sofia, Moscow, $388 \mathrm{pp}$.

Hassell K.L., Kefford B.J. \& Nugegoda D. 2006: Sub-lethal and chronic salinity tolerances of three freshwater insects: Cloeon sp. and Centroptilum sp. (Ephemeroptera: Baetidae) and Chironomus sp. (Diptera: Chironomidae). - J. Exp. Biol. 209: 4024-4032.

Hijmans R.J., Phillips S., Leathwick J.R. \& Elith J. 2012: $R$ Package “dismo" version 0.7-23. http://cran.r-project.org/ web/packages/dismo

Holzenthal R.W. 2009: Trichoptera (Caddisflies). In Likens G.E. (ed.): Encyclopedia of Inland Waters. Elsevier, Oxford, pp. 456-467.

JACKSON J.K. \& ReSH V.H. 1991: Periodicity in mate attraction and flight activity of three species of caddisflies (Trichoptera). — J. N. Am. Benthol. Soc. 10: 198-209.

Jiménez-Valverde A. \& LoBo J.M. 2007: Threshold criteria for conversion of probability of species presence to either-or presence-absence. - Acta Oecol. 31: 361-369.

KAIL J., ARLE J. \& JÄHNIG S.C. 2012: Limiting factors and thresholds for macroinvertebrate assemblages in European rivers: Empirical evidence from three datasets on water quality, catchment urbanization, and river restoration. - Ecol. Indic. 18: $63-72$.

KumANSKi K. 2007: Second addition to volume 15 (Trichoptera: Annulipalpia) and volume 19 (Trichoptera: Integripalpia) of Fauna bulgarica. - Hist. Nat. Bulgar. 18: 81-94.

Landeiro V.L., Bini L.M., Melo A.S., Oliveira Pes A.M. \& MagNUSSON W.E. 2012: The roles of dispersal limitation and environmental conditions in controlling caddisfly (Trichoptera) assemblages. - Freshw. Biol. 57: 1-11. 
Ligeiro R., Hughes R.M., Kaufmann P.R., Macedo D.R., Firmiano K.R., Ferreira W.R., Oliveira D., Melo A.S. \& Callisto M. 2013: Defining quantitative stream disturbance gradients and the additive role of habitat variation to explain macroinvertebrate taxa richness. - Ecol. Indic. 25: 45-57.

Lin Z. \& Liu H. 2006: How species diversity responds to different kinds of human caused habitat destruction. - Ecol. Res. 2: $100-106$

Liu C., Berry P.M., Dawson T.P. \& Pearson R.G. 2005: Selecting thresholds of occurrence in the prediction of species distributions. - Ecography 28: 385-393.

Macedo-Sousa J.A., Gerhardt A., Brett C.M.A., Nogueira A.J.A. \& SoAres A.M.V.M. 2008: Behavioural responses of indigenous benthic invertebrates (Echinogammarus meridionalis, Hydropsyche pellucidula and Choroterpes picteti) to a pulse of Acid Mine Drainage: A laboratorial study. - Environ. Pollut. 30: 1-8.

Macneale K.H., Peckarsky B.L. \& Likens G.E. 2005: Stable isotopes identify dispersal patterns of stonefly populations living along stream corridors. - Freshw. Biol. 50: 1117-1130.

Malicky H. 2013: Fauna Europaea: Family Hydropsychidae. Fauna Europaea, version 2.6, http://www.faunaeur.org

Merbitz H., Fritz S. \& Schneider C. 2012: Mobile measurements and regression modeling of the spatial particulate matter variability in an urban area. - Sci. Total Environ. 438: 389-403.

Múrria C., Zamora-Muñoz C., Bonada N., Ribera C. \& Prat N. 2010: Genetic and morphological approaches to the problematic presence of three Hydropsyche species of the pellucidula group (Trichoptera: Hydropsychidae) in the westernmost Mediterranean Basin. - Aquat. Insects 32: 85-98.

PANDIT R. \& LABAND D.N. 2007: Spatial autocorrelation in country-level models of species imperilment. - Ecol. Econ. 60: $526-532$

PÂrvulescu L., Zaharia C., Satmari A. \& Drãguț L. 2013: Is the distribution pattern of the stone crayfish in the Carpathians related to karstic refugia from Pleistocene glaciations? Freshw. Sci. 32: 1410-1419.

Pauls S., Lumbsch H.T. \& Haase P. 2006: Phylogeography of the montane caddisfly Drusus discolor: evidence for multiple refugia and periglacial survival. - Mol. Ecol. 15: 2153-2169.

Petrin Z., Laudon H. \& Malmevist B. 2007: Does freshwater macroinvertebrate diversity along a $\mathrm{pH}$-gradient reflect adaptation to low pH? - Freshw. Biol. 52: 2172-2183.

PhILIPSON G.N. 1969: Some factors affecting the netspinning of caddisfly Hydropsyche instabilis Curtis (Trichoptera, Hydropsychidae). - Hydrobiologia 34: 369-377.

PItsch T. 1993: Zur larval Taxonomie, Faunistik und Ökologie mitteleuropäischer Fließwasser-Köchlerfliegen (Insecta: Trichoptera). Technische Universität, Berlin, 322 pp.

Ratia H., Vuori K.M. \& Oikari A. 2012: Caddis larvae (Trichoptera, Hydropsychidae) indicate delaying recovery of a watercourse polluted by pulp and paper industry. - Ecol. Indic. 15: $217-226$

Resh V.H. \& Rosenberg D.M. 1984: The Ecology of Aquatic Insects. Praeger Publishers, New York, 625 pp.
Rizo-Patrón V.F., Kumar A., McCoy Colton M.B., Springer M. \& Trama F.A. 2013: Macroinvertebrate communities as bioindicators of water quality in conventional and organic irrigated rice fields in Guanacaste, Costa Rica. - Ecol. Indic. 29: 68-78.

Ruiz-García A., Márquez-Rodríguez J. \& Ferreras-Romero M. 2012: Implications of anthropogenic disturbance factors on the Trichoptera assemblage in a Mediterranean fluvial system: Are Trichoptera useful for identifying land-use alterations? Ecol. Indic. 14: 114-123.

Sagnes P., Mérigoux S. \& Péru N. 2008: Hydraulic habitat use with respect to body size of aquatic insect larvae: Case of six species from a French Mediterranean type stream. - Limnologica 38: 23-33.

Schmid F. 1980: Les insectes et arachnides du Canada. Genera des Trichoptères du Canada et des États adjacents. Hull, Québec, 796 pp.

SchмiтT T. 2009: Biogeographical evolutionary importance of the European high mountain systems. - Front. Zool. 6: 9.

Sснмiтt T. \& RÁkosy L. 2007: Changes of traditional agrarian landscapes and their conservation implications: a case study of butterflies in Romania. - Divers. Distrib. 13: 855-862.

StATZner B. \& DolÉDec S. 2011: Mineral grain availability and pupal-case building by lotic caddisflies: Effects on case architecture, stability and building expenses. - Limnologica 41: 266-280.

Storey R.G. \& QuinN J.M. 2013: Survival of aquatic invertebrates in dry bed sediments of intermittent streams: temperature tolerances and implications for riparian management. Freshw. Sci. 32: 250-266.

Theissinger K., Bálint M., Haase P., Johannesen J., Laube I. \& PAuls S.U. 2011: Molecular data and species distribution models reveal the Pleistocene history of the mayfly Ameletus inopinatus (Ephemeroptera: Siphlonuridae). - Freshw. Biol. 56: $2554-2566$.

Theissinger K., Bálint M., Feldheim K.A., HaAse P., Johannesen J., Laube I. \& Pauls S.U. 2013: Glacial survival and postglacial recolonization of an arctic-alpine freshwater insect ( $\mathrm{Ar}$ cynopteryx dichroa, Plecoptera, Perlodidae) in Europe. $-J$. Biogeogr. 40: 236-248.

WARINGER J.A. 1991: Phenology and the influence of meteorological parameters on the catching success of light-trapping for Trichoptera. - Freshw. Biol. 25: 307-319.

WARINGER J. \& GRAF W. 2011: Atlas of Central European Trichoptera Larvae/Atlas der Mitteleuropäischen Köcherfliegenlarven. Erik Mauch, Dinkelscherben, 468 pp.

Wolf B., Kiel E., Hagge A., Krieg H.J. \& Feld C.K. 2009: Using the salinity preferences of benthic macroinvertebrates to classify running waters in brackish marshes in Germany. - Ecol. Indic. 9: 837-847.

Yaegashi S., Watanabe K., Monaghan M.T. \& Omura T. 2014: Fine-scale dispersal in a stream caddisfly inferred from spatial autocorrelation of microsatellite markers. - Freshw. Sci. 33: 172-180.

Received February 23, 2014; revised and accepted June 20, 2014 Prepublished online October 16, 2014 